\title{
Incidence, etiology, and patterns of maxillofacial traumas in Syrian patients in Hatay, Turkey: A 3 year retrospective study
}



\begin{abstract}
1'Department of Otorhinolaryngology, Mustafa Kemal University Faculty of Medicine, Hatay-Turkey ${ }^{2}$ Department of Plastic Surgery, Mustafa Kemal University Faculty of Medicine, Hatay-Turkey

${ }^{3}$ Department of Emergency Medicine, Mustafa Kemal University Faculty of Medicine, Hatay-Turkey
\end{abstract}

\begin{abstract}
BACKGROUND: This study aimed to assess the demographics, clinical features, and treatment costs of maxillofacial trauma cases referred to our hospital during the Syrian civil war.

METHODS: The study included 80 cases of maxillofacial trauma. Patients with additional pathologies were excluded from the study. The patients were examined with respect to their demographics and clinical characteristics, Injury Severity Score (ISS), Glasgow Coma Score (GCS), treatments applied, costs, and outcomes.

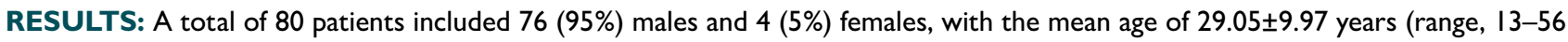
years), and $72(90 \%)$ of them were Syrians injured in the war. The most common mechanism of trauma was the firearms injury in $72(90 \%)$ cases, and the most frequently seen lesion was the mandible fracture $(n=48,60 \%)$. The ISS of all the patients was $<16$, as a severe trauma score. The GCS value was 8-12 in 4 (5\%) patients, and 15 in 76 (95\%). The most common treatment applied were the reduction and fixation, and graft-flap following fracture $(n=12,15 \%)$. The mean duration of hospitalization was I5.27 \pm 13.0 days (range, 2-60 days). All patients were discharged from hospital. The mean cost per case was calculated as 5,58I.55 \pm 56.3 Turkish Lira (range, 772-18,697 TL) or I,25I.24 I 14.2 US Dollars (US\$173-4,192). There was a significant correlation between the costs and the length of hospitalization $(p<0.001, r=+0.729)$ and trauma scores $(p=0.004, r=-0.616)$.
\end{abstract}

CONCLUSION: Firearms-injured young males with mandible fractures were the most common group of maxillofacial trauma cases seen during the Syrian war. The intensity of patients and the cost of the hospital stay have significantly increased because of the ongoing conflict in the neighboring country of Syria.

Keywords: Costs; firearms; intensity; mandible fractures.

\section{INTRODUCTION}

Maxillofacial trauma is a frequently seen type of injury, requiring diagnosis of fractures and soft tissue injuries, and a subsequent application of appropriate treatment, which may sometimes entail emergency intervention. ${ }^{[1]}$ Maxillofacial trauma is often accompanied by head trauma, and when respiratory problems and brain parenchyma injuries are involved, this represents a patient group with life-threatening injuries. For patients in a life-threatening situation, first the ABC (airwaybreathing-circulation) must be provided, and then, emergency surgery is necessary. ${ }^{[2,3]}$ The most commonly affected region in patients with maxillofacial trauma is the mandible. As the anatomic structure of the mandible is complex, an injury to facial nerves and other soft tissue damage affects the prognosis and the appearance of the patient. ${ }^{[3,4]}$

Cite this article as: Arlı C, Özkan M, Karakuş A. Incidence, etiology, and patterns of maxillofacial traumas in Syrian patients in Hatay, Turkey: A 3 year retrospective study. Ulus Travma Acil Cerrahi Derg 2019;25:29-33.

Address for correspondence: Cengiz Arli, M.D.

Mustafa Kemal Üniversitesi Tıp Fakültesi, Kulak Burun Boğaz Anabilim Dalı, 31100 Hatay, Turkey.

Tel: +90 326 - 2291000 E-mail: drkarakus@yahoo.com

Ulus Travma Acil Cerrahi Derg 2019;25(I):29-33 DOI: 10.5505/tites.2018.16243 Submitted: 17.11.2017 Accepted: 16.07.2018 Online: 26.12.2018

Copyright 2019 Turkish Association of Trauma and Emergency Surgery 
The Syrian civil war is an ongoing multisided armed conflict, in which almost II.5\% of Syria's population has been killed or severely injured, including citizens, rebels, and army forces. Patients with critical and complicated trauma injuries have been transported to neighboring countries to receive an adequate treatment. In this period, many patients have also arrived to the Hatay province in Turkey. In the present study, we aimed to assess the demographics, clinical characteristics, patient treatment, outcome, and costs of maxillofacial trauma cases from Syrian civil war, who were admitted to the Emergency Department in the province of Hatay.

\section{MATERIALS AND METHODS}

In this study, a retrospective analysis included 80 patients with maxillofacial trauma in Hatay Mustafa Kemal University Medical School between 2014 and 2017. The study protocol was approved by Research Hospital and the Medical Ethics Committee at Mustafa Kemal University (Protocol Code: 2015-13172/98).

The data obtained from the medical records of patients seeking treatment for maxillofacial trauma in the Emergency Department of Hatay Mustafa Kemal University were the basis of this study. Age, gender, fracture etiology, anatomic localization, distribution of traumas, and treatment methods were examined. Records for each patient were also taken for the Injury Severity Score (ISS), Glasgow Coma Score (GCS), the length of hospital stay, and costs. Patients with any additional pathology were excluded from the study. The lesions were classified as bone fractures, soft tissue, facial nerve, and parotid and external ear canal pathologies. Informed consent was obtained from all the patients.

The best scoring system that shows the severity of the trauma is ISS. The ISS has been defined evaluating the six regions (head/neck, face, chest, abdomen, extremities, and external) used in the Abbreviated Injury Scale (AIS) scoring system. The three regions most severely affected were taken and scored between $I$ and 5 . Then the total of the squared values was calculated ( $0-75$ points). The squared values were used because the effect of trauma in multiple injuries is greater than the effect of a single injury. A total greater than 16 was evaluated as severe and equal to or greater than 25 as very severe. Thus, the effects on morbidity, mortality, and the length of hospital stay were examined. The GCS was used in the evaluation of patient consciousness. Motor, eyes, and verbal responses of patients were evaluated in GCS. The illness was scored between 3 and 15. The scores between 3 and 8 scores are poor, between 9 and 13 are medium, and between 14 and 15 are good.

The interventions applied were grouped as graft, flap, reduction, fixation, screw, wire, plate, debridement, and facial and parotid repair. Costs were evaluated together with trauma severity and the length of hospital stay.

\section{Statistical Analysis}

The data collected from the patient files in the archive were analyzed using the SPSS version 16.0 software (IBM, Armonk, NY, USA). Categorical variables were stated as the mean \pm standard deviation. In the median values comparison, the Mann-Whitney $U$ test was used. The relationship between the study parameters was assessed using the Pearson's correlation analysis. The correlation coefficient values were defined as follows: strong correlation $(\geq 0.8)$; moderate correlation (0.6-0.8); fair correlation (0.3-0.5), and poor correlation $(\leq 0.3)$. A p-value of $<0.05$ was accepted as statistically significant.

\section{RESULTS}

In this retrospective study, a total of 80 patients with maxillofacial fractures were evaluated. There were $76(95 \%)$ males and $4(5 \%)$ females with the mean age of $29.05 \pm 9.87$ years (range, 3-56 years). There was a significant difference determined between the genders (chi square, $p<0.001$ ).

The most common etiological factor of the maxillofacial trauma was the gunshot injury in $72(90 \%)$, followed by a traffic accident in $8(10 \%)$ patients. The most common site of the fracture was the mandible $(60 \%)$ (Figs. Ia and 2a). The mean length of the hospital stay was $15.27 \pm 13.0$ days (range, $2-60$ days).
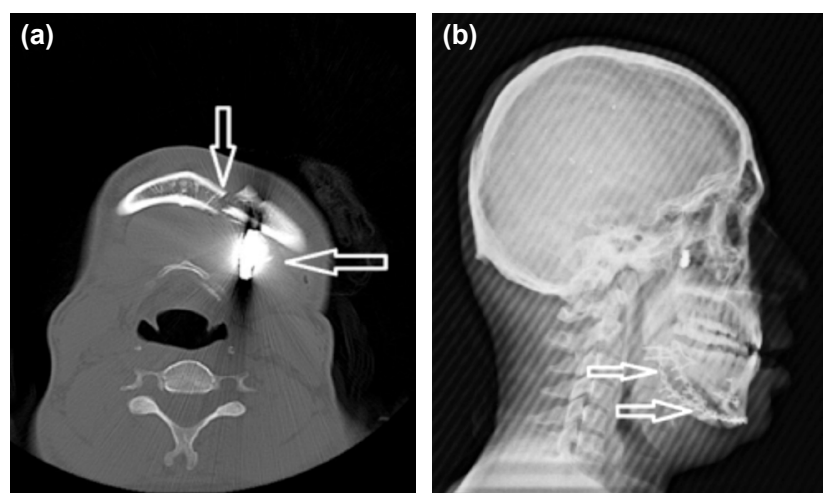

Figure 1. (a) Foreign body and the ultrafragmante sepere deplase fracture in the left mandible (preoperative). (b) Repair with screw implants and mini plate (postoperative).
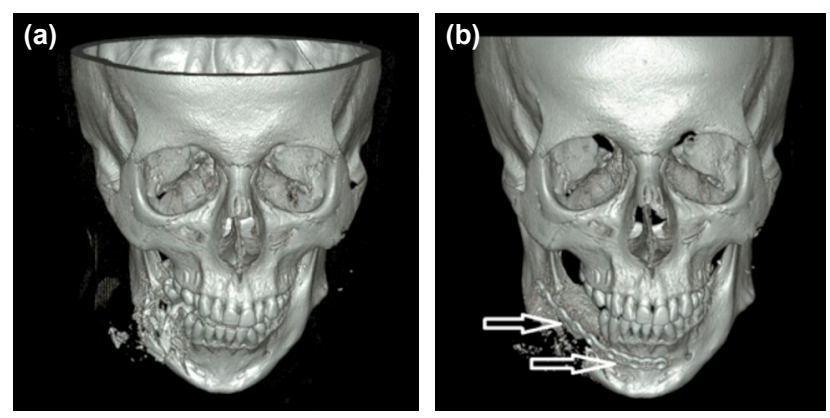

Figure 2. (a) Multifragmante deplase fractures in the right mandible ramus (preoperative). (b) Mini plate and screw implant in the right mandible ramus (postoperative). 
Table I. Distribution of types of facial fractures

\begin{tabular}{lcc}
\hline Fractures and nerve and gland injuries & \multicolumn{2}{c}{ Count } \\
\cline { 2 - 3 } & $\mathbf{n}$ & $\%$ \\
\hline Mandible & 48 & 60.0 \\
Mandible - Maxilla & 4 & 5.0 \\
Maxilla - Zygoma & 4 & 5.0 \\
Mandible - facial nerve injury & 4 & 5.0 \\
Mandible - Maxilla - external ear trauma & 4 & 5.0 \\
Mandible - Zygoma - facial nerve injury & 4 & 5.0 \\
Mandible - facial nerve injury -parotid injury & 4 & 5.0 \\
Maxilla - Zygoma - facial nerve injury & 4 & 5.0 \\
Mandible - Maxilla - Zygoma - facial nerve injury & 4 & 5.0 \\
Total & 80 & 100 \\
\hline
\end{tabular}

Table 2. The distribution of surgery techniques according to the facial bone fractures

\begin{tabular}{lcc}
\hline & \multicolumn{2}{c}{ Count } \\
\cline { 2 - 3 } & $\mathbf{n}$ & $\%$ \\
\hline Grafting - flapping & 12 & 15.0 \\
Fixation - reduction & 12 & 15.0 \\
Reduction & 4 & 5.0 \\
Screw implants & 4 & 5.0 \\
Grafting - flapping - debridement & 4 & 5,0 \\
Fixation - wire & 4 & 5.0 \\
Fixation - mini plate & 4 & 5.0 \\
Wire - reduction & 4 & 5.0 \\
Reduction - facial repair & 4 & 5.0 \\
Debridement - mini plate & 4 & 5.0 \\
Mini plate - screw implants & 4 & 5.0 \\
Grafting - flapping - mini plate - screw implants & 4 & 5,0 \\
Grafting - flapping - mini plate - facial repair & 4 & 5.0 \\
Fixation - reduction - mini plate & 4 & 5.0 \\
Reduction - mini plate - screw implants & 4 & 5.0 \\
Grafting - flapping - parotid repair - mini plate - & & \\
facial repair & 4 & 5.0 \\
Total & 80 & 100 \\
\hline & &
\end{tabular}

Demographic and clinical characteristics of patients with maxillofacial trauma are shown in Table I.

In the ISS evaluation of the patients, all were below the critical value of $<16$. The GCS was determined to range between 8 and 12 in 4 (5\%) patients, and it was 15 in 76 (95\%) patients. The treatment protocol is summarized in Table 2. Fixation and reduction were applied to 12 (15\%) patients, and graft-
Table 3. The distribution of clinics where patients are treated

\begin{tabular}{lcc}
\hline Clinic & $\mathbf{n}$ & $\%$ \\
\hline Plastic surgery clinic & 52 & 65.0 \\
Ear nose throat clinic & 24 & 30.0 \\
Anesthesia intensive care clinic & 4 & 5.0 \\
Total & 80 & 100 \\
\hline
\end{tabular}

flap was applied to 12 (I5\%) (Figs. Ib and $2 \mathrm{~b}$ ). The clinics where the patients were treated are shown in Table 3 . The mean cost per patient was calculated as $5,581.55 \pm 56.3$ Turk-


(US\$ 173-4, 192). A positive correlation was found between the length of hospital stay and cost $(p<0.001)$. There was a significant moderately strong correlation between the cost and hospitalization length $(p<0.001, r=+0.729)$, and trauma scores $(p=0.004, r=-0.616)$.

\section{DISCUSSION}

There is an increasing incidence of head and neck trauma in modern warfare. In particular, when the degree of efficiency of explosive materials is high, this rate increases. ${ }^{[1-4]}$ Firearms injuries are rarely seen in general, but the frequency increases in war, and they are often seen in young males. ${ }^{[5-7]}$ When the injuries caused by the conflict in Syria are examined, which is taking place in our region, it can be seen that young males are the population often injured by bombs and shrapnel. Keller et al. ${ }^{[8]}$ in their study mentioned that 239 maxillofacial trauma patients who were assessed during the war were young men (99.2\%).

Trauma to the lower region of the face is often seen following maxillofacial trauma. Fractures of the orbital and maxillary and zygomatic fractures may be seen after trauma. A previous study reported that orbital fractures were most often encountered, ${ }^{[1]}$ whereas in the literature, the mandible is the most commonly affected bone in the case of injuries of the lower region of the face. Another study about maxillofacial trauma reported that mandible fractures were the most common fractures with the ratio of $33.4 \% .{ }^{[9]}$ In the current study, mandible fractures were the most common injuries, just like in the previous study.

Maxillofacial trauma constitutes a problem group with respect to airway control, especially in emergency and anesthesia. There can be problems in the acute period such as airway and intracranial injuries. Especially, patients with complicated mandible fractures have difficult airway management. ${ }^{[10]}$

Bahouth et al. mentioned that 12 out of 50 patients with mandible fractures caused by shrapnel needed acute intubation because of airway obstruction. ${ }^{\left[{ }^{11]}\right.}$ Keller et al. ${ }^{[8]}$ reported that $5 \mathrm{I} .4$ of the maxillofacial trauma patients underwent 
acute intubation because of the airway obstruction during the war. None of our maxillofacial trauma patients needed acute intubation.

In the later period, there may be a soft tissue infection, function loss, and cosmetic problems. ${ }^{[12]}$ In addition to bone fractures, soft tissue, and facial nerve injures may be seen during maxillofacial trauma. In cases determined with fracture, fixators such as screws, wire, or a plate may be used for fixation following reduction. In addition, the facial nerve, parotid, and soft tissue repair are necessary, and if there is a tissue defect, the application of graft and flap is required. In the treatment of these types of injuries, a multidisciplinary approach is suitable with a follow-up and rehabilitation of the patient by brain surgeons, neurologists, and plastic surgeons. ${ }^{[1,13,14]}$ Regarding the subject of repair, the importance of operations to be performed by the ear, nose, and throat and plastic surgeons is paramount. Patient prognosis and the sequelae, which could develop, should be monitored through a regular follow-up.

In the evaluation of trauma severity, various trauma classifications are used such as the Revised Trauma Score (RTS), AIS, ISS, and the Trauma Injury Severity Score. In a study of 100 polytrauma patients by Karakuş et al., trauma severity was compared with the length of hospital stay, and the results of the ISS, RTS, and GCS were found to be significant. ${ }^{[15]}$ In the same study, when the severity of trauma and mortality rates were compared, the ISS was determined as the most significant trauma score. ${ }^{[1,16]}$ In patients with head trauma, the best follow-up parameter for the brain parenchyma involvement is GCS. In the cases that were followed up in this study, the ISS values were all below the critical level of 16 , and the GCS values were determined as 15. The patients who were included in the current study had a low ISS and high GCS because of having only maxillofacial trauma and no injury in other parts of the body.

When the trauma scores of the patients, the length of hospital stay, the outcomes, and costs were evaluated, they were found to be significantly consistent with previous reports in the literature.

In a study by Allareddy Nalliah et al. ${ }^{[17]}$ in the United States using the Nationwide Inpatient Sample, assault was found to be the leading cause (36.5\%) of hospitalization for the reduction of facial fractures, followed by motor vehicle accidents (16\%), falls (15\%), and other transportation accidents (3.5\%). In a study conducted in southern Turkey, Erol et al. ${ }^{[8]}$ reported that the most common etiological factor in maxillofacial trauma were traffic accidents ( 1,104 patients, 38\%), closely followed by falls (I,065 patients, $36.7 \%$ ).

The causes of the maxillofacial trauma were determined as a motor vehicle accident in I, 104 (38\%), falls in 1,065 (36.7\%), and assault in $10 \%$. Similarly, in a 2014 study by Arslan et al. ${ }^{[19]}$ 754 patients in the Ankara region were reviewed.
Atilgan et al. ${ }^{[16]}$ examined cases in the period from 2000 to 2005 and reported that the most common cause of maxillofacial injury in young patients are falls (65\%), and in adults, the primary cause were road traffic accidents (88\%). Similarly, Bereket et al. ${ }^{[20]}$ found that falls (40.2\%) were the major cause of mandible fractures, followed by traffic accidents and assault. The fractures were seen in the mandible anatomical sites of the condyle (34.6\%), body, and symphysis.

Mass events such as natural disasters, wars, and bombings increase patient traffic in hospitals and especially in Emergency Departments, making the functioning more difficult and increasing costs. In these cases, disaster plans are put into operation in hospitals. However, unwanted events entail cost evaluations, and accounts are negatively affected. ${ }^{[15]}$ In a cost-effective study, a long treatment period of the patients injured during war and a negative effect of this condition on the overall budget was reported. ${ }^{[21]}$

When the mean costs of the cases not injured in the war were compared to the costs of cases following the war, a two-fold increase was found. This was defined as a negative effect on both the hospital budget and the general health care budget.

\section{Conclusion}

Young males with mandible fractures caused by firearms were the most common group of the maxillofacial trauma patients during the Syrian war. The intensity of patients, hospital workload, and costs were determined to have increased because of the ongoing conflict in the region.

Conflict of interest: None declared.

\section{REFERENCES}

1. Keller MW, Han PP, Galarneau MR, Gaball CW. Characteristics of maxillofacial injuries and safety of in-theater facial fracture repair in severe combat trauma. Mil Med 2015;180:315-20. [CrossRef]

2. Brennan J. Head and neck trauma in Iraq and Afghanistan: different war, different surgery, lessons learned. Laryngoscope 2013;123:2411-7.

3. Feldt BA, Salinas NL, Rasmussen TE, Brennan J. The joint facial and invasive neck trauma (J-FAINT) project, Iraq and Afghanistan 2003 2011. Otolaryngol Head Neck Surg 2013;148:403-8. [CrossRef]

4. Levin L, Zadik Y, Peleg K, Bigman G, Givon A, Lin S. Incidence and severity of maxillofacial injuries during the Second Lebanon War among Israeli soldiers and civilians. J Oral Maxillofac Surg 2008;66:1630-3.

5. Karakuş A, Yengil E, Akkücük S, Cevik C, Zeren C, Uruc V. The reflection of the Syrian civil war on the emergency department and assessment of hospital costs. Ulus Travma Acil Cerrahi Derg 2013;19:429-33.

6. Inci M, Karakuş A, Rifaioglu MM, Yengil E, Atçi N, Akin Ö, et al. A practice report of bladder injuries due to gunshot wounds in Syrian refugees. Ulus Travma Acil Cerrahi Derg 2014;20:371-5. [CrossRef]

7. Uruc V, Ozden R, Duman IG, Dogramaci Y, Yengil E, Karapınar S, et al. Major musculoskeletal injuries and applied treatments in the current conflicts in Syria. Acta Medica Mediterranea 2014;30:637-44.

8. Keller MW, Han PP, Galarneau MR, Brigger MT. Airway Management 
in Severe Combat Maxillofacial Trauma. Otolaryngol Head Neck Surg 2015;153:532-7. [CrossRef]

9. Abramowicz S, Allareddy V, Rampa S, Lee MK, Nalliah RP, Allareddy V. Facial Fractures in Patients with Firearm Injuries: Profile and Outcomes. J Oral Maxillofac Surg 2017;75:2170-6. [CrossRef]

10. Jose A, Nagori S, Agarwal B, Bhutia O, Roychoudhury A. Management of maxillofacial trauma in emergency: An update of challenges and controversies. J Emerg Trauma Shock 2016;9:73-80. [CrossRef]

11. Bahouth H, Ghantous Y, Rachmiel A, Amodi O, Abu-Elnaaj I. Maxillofacial Injuries Related to the Syrian War in the Civilian Population.J Oral Maxillofac Surg 2017;75:995-1003. [CrossRef]

12. Available at: http:www.acilci.net. Accessed Sep 20, 2017.

13. Lew TA, Walker JA, Wenke JC, Blackbourne LH, Hale RG. Characterization of craniomaxillofacial battle injuries sustained by United States service members in the current conflicts of Iraq and Afghanistan. J Oral Maxillofac Surg 2010;68:3-7. [CrossRef]

14. Breeze J, Gibbons AJ, Shieff C, Banfield G, Bryant DG, Midwinter MJ. Combat-related craniofacial and cervical injuries: a 5-year review from the British military. J Trauma 2011;71:108-13. [CrossRef]
15. Karakuş A, Kekeç Z, Akçan R, Seydaoğlu G. The relationship of trauma severity and mortality with cardiac enzymes and cytokines at multiple trauma patients. Ulus Travma Acil Cerrahi Derg 2012;18:289-95.

16. Atilgan S, Erol B, Yaman F, Yilmaz N, Ucan MC. Mandibular fractures: a comparative analysis between young and adult patients in the southeast region of Turkey.J Appl Oral Sci 2010;18:17-22. [CrossRef]

17. Allareddy V, Allareddy V, Nalliah RP. Epidemiology of facial fracture injuries. J Oral Maxillofac Surg 2011;69:2613-8. [CrossRef]

18. Erol B, Tanrikulu R, Gorgun B. Maxillofacial Fractures. Analysis of demographic distribution and treatment in 2901 patients (25-year experience). J Craniomaxillofac Surg 2004;32:308-13. [CrossRef]

19. Arslan ED, Solakoglu AG, Komut E, Kavalci C, Yilmaz F, Karakilic E, et al. Assessment of maxillofacial trauma in emergency department. World J Emerg Surg 2014;9:13. [CrossRef]

20. Bereket C, Şener I, Şenel E, Özkan N, Yılmaz N. Incidence of mandibular fractures in black sea region of Turkey. J Clin Exp Dent 2015;7:e4103. [CrossRef]

21. Karakus A, Kuvandik G, Atalay E. Evaluation of Extremity Injuries Presented to Emergency Department. Arch Iran Med 2017;20:646-8.

\section{ORIJIINAL ÇALIŞMA - ÖZET}

\section{Türkiye Hatay'daki Suriyeli maksillofasial travmalı hastaların insidansı,} etyolojisi ve örneği: Üç yıllık geriye dönük çalışma

\section{Dr. Cengiz Arlı, ${ }^{1}$ Dr. Mustafa Özkan, ${ }^{2}$ Dr. Ali Karakuş ${ }^{3}$}

${ }^{1}$ Mustafa Kemal Üniversitesi Tıp Fakültesi, Kulak Burun Boğaz Anabilim Dalı, Hatay

${ }^{2}$ Mustafa Kemal Üniversitesi Tıp Fakültesi, Plastik Cerrahi Anabilim Dalı, Hatay

${ }^{3}$ Mustafa Kemal Üniversitesi Tıp Fakültesi, Acil Tıp Anabilim Dalı, Hatay

AMAÇ: Bu çalışmada Suriye'deki sivil savaş sırasında hastanemize getirilen maksillofasial travmalı olguların demografik, klinik özellikleri, tedavileri ve maliyetlerinin değerlendirilmesi amaçlanmıştır.

GEREÇ VE YÖNTEM: Maksillofasial travmalı 80 olgu çalısmaya dahil edildi. Ek patolojisi olan olgular çalışma dışı bırakıldı. Olgular demografik ve klinik özellikleri, Injury Severity Score (ISS), Glaskow Koma Skoru (GKS), uygulanan tedaviler, maliyetleri ve sonuçları açısından incelendi.

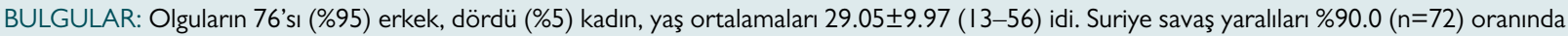
idi. En sık travma oluş mekanizması ateşli silah yaralanması 72 (\%90.0) idi. En sık lezyonun mandibula kırı̆ı ( $n=48, \% 60.0)$ olduğu saptandı. ISS değeri tüm hastalarda şiddetli travma değeri olan 16'nın altında bulundu. GKS değeri dört (\%5) hastada 8-12, 76 (\%95) hastada 15 olarak tespit edildi. Kırık sonrası tespit, redüksiyon ve greft-flep uygulamaları $(n=12$, \% I5) en sık yapılan tedavi uygulamaları idi. Ortalama yatı̧ süresi I5.27 I I3.0 (2-60 gün)


Travma skoru $(p=0.004, r=-0.616)$, hastanede kalış süresi $(p<0.001, r=+0.729)$ ve maliyet arasında önemli derecede uyumluluk vardı. TARTIŞMA: Suriye savaşı sırasında görülen maksillofasial travmalı olgularda ateşli silah yaralanmalı mandibula kırıklı genç erkekler en sık görülen gruptu. Komşu ülke Suriye'deki savaş nedeniyle hastane yoğunluk ve maliyetinin arttığı belirlendi.

Anahtar sözcükler: Ateşli silah; maliyet; mandibula kırı̆̆ı; yoğunluk.

Ulus Travma Acil Cerrahi Derg 2019;25(I):29-33 doi: 10.5505/tites.2018.16243 